\title{
Perceptions of the value of Collective Worship amongst trainee teachers in England
}

Imran Mogra

School of Education, Faculty of Health, Law and Social Sciences, Birmingham City

University, Birmingham, England.

Imran.mogra@bcu.ac.uk

Attwood Building

Franchise Street

City North Campus

Perry Barr

Birmingham

B42 2SU

\begin{abstract}
This article draws on a survey conducted with primary school trainee teachers in a university in England. It set out to investigate their knowledge, understanding and their view about the role that Collective Worship plays in schools. A sample of 125 participants contributed to the findings of this inquiry by completing a questionnaire. The results demonstrate that these students think that Collective Worship makes a significant contribution to the spiritual, moral, social, cultural, emotional (SMSC) and intellectual development of pupils. The most significant finding is that they think worship should be retained. Their views are important as they provide further insights for the debates currently taking place about the status and nature of worship in schools. The research has implications for further studies and to develop the overall knowledge about Collective Worship among trainee teachers.
\end{abstract}

\section{Key words: collective, worship, trainee, teacher, school, SMSC}

\section{Introduction}

A recent visit to a school for a typical Key Stage 1 celebration and attendance assembly revealed several features: it was held in the morning as a first collective activity led by a senior member of staff; teachers, support staff and a handful of parents were in attendance; certificates, badges, stars, an attendance teddy and lists of names were all prepared in advance. After the usual greetings and welcoming of parents, the routine of calling children forward and rewarding them was completed in about 25-30 minutes. At the end, the following types of celebrations were evident: Star of the Week for best work; club badges for arithmetic tests; birthdays in the week; Good to be Green for behaviour, Attendance Ted for $100 \%$. An evident omission was that of Collective Worship (CW) or a 'moment of reflection'. Thus, in law, at the practical level, this would illustrate non-compliance regardless of whether the school had been granted determination or not (DfE 1994).

At the school community level, however, ordinarily, the coming together of teachers and children, and on some occasions, members of the wider community, including parents and others, in a school event like the one captured above would be celebrated by everyone. However, in Britain, this does not seem to be the case. CW, distinct from assemblies, is a problematic school activity required by law (Cheetham 2000; Felderhof 2000; Louden 2008). 
In England, Northern Ireland and Wales, a majority of schools are legally bound to provide daily acts of worship for their pupils. In Scotland the requirement is to provide religious observance. In the former countries this duty was introduced from the settlement made in the Education Act 1944, whereas, in the latter, the Education (Scotland) Act 1872 (Cumper and Mawhinney 2015). In England, worship in community schools without a religious character must be wholly or mainly of a broadly Christian character. Academies and free schools without a religious character are required to provide collective worship in line with each school's funding agreement with the Government (Cumper and Mawhinney 2015). Schools can apply for a disapplication of the Christian collective worship requirement to allow a school to organise an alternative form of worship should it be required by parents and/or guardians. Parents have also got a right to withdraw their children from CW (Khan 1995; Louden 2004; Cumper and Mawhinney 2015).

In 2014 an anonymous letter created one of the most serious scandals that the City of Birmingham in England has faced in recent years. The letter referred to "Operation Trojan Horse" - a plot by some Muslim groups to install governors at some schools, to secure control and ensure part of their policies and practices were in line with principles advocated by a "conservative" version of Islam (Pecenka and Anthias 2014). This led to multiple formal investigations and emergency inspections of the schools thought to be identified in the letter (Arthur 2015). The "Trojan Horse" (THA) affair, though confined to a few of Birmingham's many schools, raised many issues about school governance, leadership, school ethos and improvement, curriculum and equality, the relationship between religion and education, and political ideology and systems of education (Mogra 2016).

\section{Literature review}

Nationally, CW has resurfaced in the public consciousness as a controversial issue in relation to its status, nature, value and provision in British schools. The debate was reinforced during what came to be known as the 'Trojan Horse affair' in Birmingham as, once again, the nature of the worship and questions about its scrutiny was raised (Arthur 2015). Some prominent figures called for the removal of what they saw as the root of the problem in meeting the religious needs of some children in schools. For instance, Professor Tim Brighouse, a former Chief Education Officer in Birmingham, questioned whether part of 'promoting British values' involved discontinuing the requirement that schools should have an act of CW mainly or wholly of Christian character (Brighouse 2014). In addition, the Chief Education Officer of the Church of England voiced support for dropping compulsory Christian assemblies and advocated a time for 'spiritual reflection' containing elements of Christianity and other major religions (Bingham 2014). Similarly, the Humanist Society argued that in a pluralist society, schools should be holding inclusive assemblies that forward the spiritual, moral, social and cultural development of all pupils and staff, regardless of their religious or non-religious beliefs (BHA 2015).

One of the reports investigating the THA concurred with some of these views and recommended that Birmingham City Council (BCC), 'with its partners, should consider leading a debate about the requirements of secular schools to provide a daily act of collective worship which must be 'wholly, or mainly of a broadly Christian character' (Kershaw 2014, 21). However, some within Catholic Education Service responded by maintaining that 'the current 
guidance is flexible to meet the needs of each school's community while respecting Christians traditions' (Pope 2014).

The THA also exposed the vulnerability of the systems in place, to support schools and governors in providing appropriate acts of worship to their pupils. In three reports, Ofsted made reference to $\mathrm{CW}$. For example, in demonstrating inadequate governance in an academy they stated: 'Currently, the academy has a weekly whole-school assembly, which is of an Islamic character. The governing body has not received permission from the Education Funding Agency for an exemption from providing a broadly Christian act of worship' (Ofsted $2014 a, 8)$. Thus, according to Ofsted, this meant that the governing body was failing to meet this aspect of their responsibilities. On the other hand, Arthur (2015) suggests that the Department for Education did not take seriously the collective worship responsibilities it had acquired through its policies in these schools.

Similarly, even when exemptions are sought, other challenges can emerge. In another report it found: '[t]he Determination awarded to the academy in January 2008, exempting the academy from having a daily, broadly Christian act of worship, expired in January 2013 and was not renewed. Currently, the academy has two Islamic faith assemblies each week and additional, optional Friday prayer. Birmingham City Mission has been delivering Christian Acts of Collective Worship at [...school], once a term, since 2006...' (Ofsted 2014b, 7). In a third school, it reported that CW was 'regular. Parents are invited to class assemblies about festivals that are in the world faith calendar' (Ofsted 2014c, 3).

A Group tasked by BCC to investigate matters raised by the THA, reached the conclusion that THA had exposed broader and inevitably contentious issues which are not Birminghamspecific, but were essentially national issues such as the purpose and role of faith and worship within the education system (BCC 2014). The Group felt that these matters should be addressed through mature, evidence based debate and with much greater precision in the use of terminology, than has been seen generally over recent months (BCC 2014, 7). Clarke's investigation into the THA did not find nor report anything substantive on the subject other than the manner in which the news of a vote in favour of Determination had been shared on a WhatsApp network (Clarke 2014). Moreover, the House of Commons Education Select Committee's report on Extremism in schools: the Trojan Horse affair, makes reference to worship in the context of criticising the Government for not making an official response to the Kershaw report (Kershaw 2014; HMSO 2015). The report was for the Birmingham City Council and contained recommendations on the requirement on schools to provide a daily act of collective worship wholly or mainly of a broadly Christian character (HMSO 2015, 1314).

The THA illustrates at least three challenges for some schools: the purpose and role of faith and worship in education; meeting the requirement of worship to be wholly, or mainly of a broadly Christian character so that worship becomes more meaningful; and, to fulfil practical and/or other requirements should disapplication be granted.

In an attempt to address wider questions related to the place of religious education, including CW, in all schools, Clarke and Woodhead (2015) published a pamphlet, A New Settlement: Religion and Belief in Schools, as a result of The Westminster Faith Debates, which brought 
together leading academic and public figures, to debate the latest research on religion and values. In their report, they argued that the old educational settlement between church and state which was formalised in the 1944 Education Act, and reflected a different era, no longer served its purpose for the benefit of schools, religion and wider society. They suggested that the time had come for a new settlement in the relationship between religion and schools. Of their twenty-two recommendations, which represent their personal views and have been formed, according to them, on the basis of relevant recent research, and their respective expertise in politics and religion, the first one relates to the Act of Collective Worship. They suggest that the current requirement in statute for an Act of Collective Worship should be abolished, and the decision about the form and character of school assemblies should be left to the governors of individual schools. Schools should be required, they recommend, to set out their statement and strategy for promoting spiritual, moral, social and cultural education, with school community assemblies as an important part of that strategy, upon which they would be inspected by Ofsted. The government should provide non-statutory guidance to help achieve this (Clarke and Woodhead 2015, 63-64).

However, previously, at the political level, only 31 MPs had supported an early day motion on the subject. The motion wished to free schools from prescriptive legal regimes. It maintained that teachers and others have repeatedly opposed this provision and it noted the diversity of society and rights to freedom of conscience, thought and belief as protected in domestic law. Similarly, it noted the educational value of inclusive school assemblies and their role in supporting shared values and the school community and ethos. Finally, it called on the Government to repeal the requirement for compulsory worship in schools and to encourage schools to hold educational assemblies that will include all children (Huppert 2010).

The lack of political will to refine the settlement is also discernible from David Bell, a previous Chief Inspector of Schools, who first became well known when he called for the removal of the legal obligation upon English schools to provide a daily act of Collective Worship (Parker, Freathy and Francis 2014). To discover how his conception of Religious Education had changed and continued throughout his professional life, Parker, Freathy, and Francis (2014), conducted an oral history interview on 12 August 2010 with Bell who had been an Education Permanent Secretary of the Department for Education (2006-12). Bell believed that RE would have a particular place because of the history of this country and the very strong established faith system in the state school system. However, in relation to CW, he thought that there was "something deep in the psyche about that. ... Politicians have only got a limited amount of political capital to expend. Is this the sort of thing you are going to expend it on?" (Parker, Freathy and Francis 2014).

These debates appear to have culminated in the availability of three options as expressed at a conference on Collective Worship and Religious Observance in Schools: An Evaluation of Law and Policy in the UK. It was strongly recommended that governments in the UK should urgently consider afresh the rationale underlying the duties of CW and religious observance in schools. The conference heard that there was currently no accepted rationale - and only when one is agreed can there then be an informed debate on whether the current duties should be maintained or amended. The report recommended that if there was rationale to be found for a collective activity in schools, then the current duties should be abolished. The report also acknowledged that the different countries in the UK may choose to take different 
approaches to the question of whether to maintain, abolish or amend the duty in light of the aims and values of each country's education system (Cumper and Mawhinney 2015). However, with the increased 'freedom' which schools are being given and the movement towards academisation and free schools, with certain limits imposed in the state sector, there could be a reflection of this in relation to $\mathrm{CW}$ with each school having its own distinctive ethos and values and allowing each school to declare its position (Cheetham 2004), as is being done with other matters.

The question about worship in school is linked with the question of religion in society, the role and relationship of religion and education and individual conceptions of education. The Woolf Institute convened an independent commission to undertake a systematic review of the role of religion and belief in contemporary UK (Butler-Sloss 2015). One of the areas it looked into was education. It sought to provide a basis for deliberation and policy-making based on research and evidence, the needs of society and the daily experiences of increasingly diverse communities. The Woolf report gathered evidence from a wide range of people and received expert testimonies on educational landscapes as well. The report noted that the arguments in favour of retaining compulsory Christian worship in UK schools were no longer convincing (Butler-Sloss 2015). However, it found widespread support for an alternative provision, as distinct from abolition. Perhaps, as evidence of some move to there being a political will for change, the commission called on all Governments across the UK to 'repeal requirements for schools to hold acts of collective worship or religious observance' and to 'issue new guidelines building on current best practice for inclusive assemblies and times for reflection that draw upon a range of sources, that are appropriate for pupils and staff of all religions and beliefs, and that will contribute to their spiritual, moral, social and cultural development' (Butler-Sloss 2015, 35-38).

The above reports seem to be pointing towards releasing maintained schools from the legal requirement of providing Christian worship, apparently a widely held concern. There is also a suggestion of maintaining some form of collectivity in whatever is provided to pupils related to this 'activity'. Moreover, the 'activity' has to have a purpose in that it is meaningful and, distinct from other activities and which contributes to their spiritual, moral, social and cultural development. These reports seem to have steered away from referring explicitly to reverence or veneration paid to a divine being or power (DfE 1994).

The brief overview above highlights the main recent reports on $\mathrm{CW}$ which, among other issues, identifies a need for further empirical evidence to supplement the analysis and provide additional data from other sources. Against the background of these concerns and debates, this article attempts to highlight a gap in empirical research.

In this article, the question of $\mathrm{CW}$ is approached from the perspectives of trainee teachers. Hitherto, little attention appears to have been paid to their thoughts about CW and the role, if at all, that it can play in contributing to the holistic development of pupils. This lack of consideration exposes a gap in understanding how the status, nature, value and provisions are interpreted at the training level. Their views might provide insights for the theoretical discussions currently under way. This article attends to these matters by drawing on research undertaken with undergraduate students. 


\section{Methodology}

\section{Purpose}

The purpose of this study was to investigate trainee teachers' knowledge, understanding, viewpoints and perceptions about $\mathrm{CW}$ and matters related to it in primary schools. In so doing, the survey specifically attempted to: ascertain their awareness and familiarity regarding the legal status of $\mathrm{CW}$ and its value; investigate the extent to which $\mathrm{CW}$ contributes to the spiritual, moral, social, cultural, emotional and intellectual development of children, and the development of a sense of community; to find out whether CW should be abolished and whether CW confuses children's faith position. In the absence of any research linking the role that $\mathrm{CW}$ could play in contributing to the universal outcomes as espoused in what was the Every Child Matters agenda (HMSO 2003), this study also investigated their views about the contribution that CW could make in meeting the outcomes of that agenda. The aim of the Every Child Matters agenda was to ensure that every child had the chance to fulfil their potential by reducing levels of educational failure, ill health, substance misuse, teenage pregnancy, abuse and neglect, crime and anti-social behaviour among children and young people (HMSO 2003). Following consultations with young people, the five outcomes which mattered most to them being healthy, staying safe; enjoying and achieving; making a positive contribution and economic well-being (Colverd and Hodgkin 2011). The research also elicited the range and nature of their experiences during their teaching practices and to identify their future needs.

\section{Ethics}

A researcher's authority to conduct research comes with a responsibility to guide, protect, and oversee the interests of the people being studied (Neuman 2014). To meet these, prior to commencing the research, faculty ethical approval was sought. Thereafter, the aims of the research were shared with all participants. They were informed that they were not obliged to participate and their completion of the questionnaire was voluntary. Students were instructed not to write their names and were also informed that the results were to be made public and, therefore, their confidentiality and anonymity was guaranteed as it allowed them to feel confident in providing their perspectives or experiences (Curtis, Murphy and Shields 2014). All students were informed that the research was not related to any module and assessment and that it would not affect their studies whether they participated or withdrew. However, the value of their contribution was acknowledged. They were informed that they could ignore any question that they did not want to respond to.

\section{Participants}

A survey was conducted and two individual interviews with academics representing Religious Education and educational policy disciplines. In addition, three focus group interviews were held with a total of twelve pupils from an inner city and a semi-rural primary school in Birmingham. These children were from diverse cultural and religious backgrounds, both boys and girls were included. Three group interviews were also held with a total of eight female students from diverse religious and cultural backgrounds. Moreover, postal questionnaires were distributed to 15 students representing specific religious traditions in this cohort. However, the data provided in this article are from the survey only, which was conducted in an English Initial Teacher Training institution (ITT) involving undergraduate students in the final year of their Bachelor of Education (QTS) course. 
The survey instrument

Multiple research methods were used for this research to develop a sophisticated picture of the phenomenon under study (Creswell 2014). The survey enabled the collection of a representation of views from the population of interest by collecting the same information from each participant. It assisted in collecting information and numeric trends on attitudes, perceptions, opinions or behaviour (Curtis, Murphy and Shields 2014). As a self-administered questionnaire, it offered the advantage of allowing students to respond, freely and without intrusion, to a sensitive and controversial topic (Creswell 2014). The questionnaire was piloted with students outside the targeted cohort to identify potential problems affecting the quality of responses. In addition, two academics reviewed it so that the outcomes of the survey were meaningful. The pilot study allowed some omissions to be identified in the questions initially asked. It also strengthened the study by improving its structural items.

The first section was designed to gather a profile of the trainees in terms of the gender, age, religious affiliation and/or personal persuasions, ethnicity and heritage. In the second section, students chose responses to closed questions about areas concerning the legal requirements of $\mathrm{CW}$. These questions were followed by three open ended questions exploring their understanding of $\mathrm{CW}$ and the value it had in school for children and the community. The third section was concerned with their teaching practice and whether they had any challenges with $\mathrm{CW}$. In the next section, their opinions, using a five-point Likert Scale on statements, related to the status of CW and the significant contribution that CW made to the 'whole' child were investigated. Thereafter, their ideas were sought on how CW could contribute to other aspects related to the well-being of children as reflected in what was the ECM agenda. The sixth section explored their future training provisions.

\section{Procedure}

At least eight lecturers in different subject areas were provided with survey questionnaires to distribute to their students prior to their teaching session. This yielded 79 initial returns. At a later date, those subject groups who did not have a session on the initial day were given the questionnaire when the entire year group had gathered for a lecture. This strategy yielded a further 46 responses.

\section{Findings}

In total there were 125 respondents from 146 distributed questionnaires. This yielded a return rate of $85.62 \%$. In this article, the findings of three sections are presented: their profile, legality about $\mathrm{CW}$ and $\mathrm{CW}$ and the whole child.

Of these 115 were female (92\%) and 9 (7.2\%) were male. There was one respondent who did not declare their gender $(0.8 \%)$. This shows that the majority of the respondents were female.

In terms of age, the data showed that there were $33(26.4 \%)$ respondents who declared themselves to be under $21,79(63.2 \%)$ between $22-27$ and 13 (10.4\%) 28 and over.

Overall there were 22 religious traditions mentioned by the respondents. Of those declaring religious traditions, Christians were the largest group consisting of $81(64.8 \%)$ respondents. There were 12 (9.6\%) atheists, eight (6.4\%) Muslims, five (4\%) Sikhs, five respondents who declared none, four stated they were unsure and a further four declared not applicable. 
In terms of their ethnic distribution, 98 (78.4\%) declared themselves to be White British and seven (5.6\%) chose not to respond. There was one declaration of each of White Irish, Polish, Chinese and Christian. There were five indications of mixed heritage, of which two were French British White and one each of Cypriot Arab, French Czech and Jamaican/Chinese/Spanish/British. There were five indications of Asian Indians, four Asian Pakistanis, one British Indian and one Bangladeshi British.

In the second section respondents were presented with five statements. For each, they were invited to choose either true, false or don't know. The table below shows their responses.

[Table 1 near here]

In essence the data reveals two main facets about the knowledge which trainees have

\begin{tabular}{|c|c|c|c|c|c|c|c|c|}
\hline \multirow[b]{2}{*}{$\begin{array}{l}\text { Collective worship is not a daily } \\
\text { statutory requirement }\end{array}$} & \multicolumn{2}{|c|}{ True } & \multicolumn{2}{|c|}{ False } & \multicolumn{2}{|c|}{$\begin{array}{l}\text { Don't } \\
\text { know }\end{array}$} & \multicolumn{2}{|c|}{$\begin{array}{l}\text { Missing } \\
\text { data }\end{array}$} \\
\hline & 61 & $48.8 \%$ & 38 & $30.4 \%$ & 23 & $18.4 \%$ & 3 & $2.4 \%$ \\
\hline $\begin{array}{l}\text { Parents have a legal right to withdraw } \\
\text { their children from } \mathrm{CW}\end{array}$ & 117 & $93.6 \%$ & 5 & $4 \%$ & 1 & $0.8 \%$ & 2 & $1.6 \%$ \\
\hline $\begin{array}{l}\text { Collective worship must take place in } \\
\text { the morning }\end{array}$ & 3 & $2.4 \%$ & 105 & $84 \%$ & 14 & $11.2 \%$ & 3 & $2.4 \%$ \\
\hline $\begin{array}{l}\text { Teachers have no choice - it is } \\
\text { compulsory for them to deliver } \mathrm{CW}\end{array}$ & 20 & $16 \%$ & 73 & $58.4 \%$ & 28 & $22.4 \%$ & 4 & $3.2 \%$ \\
\hline
\end{tabular}

regarding the above legal features of CW. A considerable gap is exposed about their knowledge of the legal status whereas knowledge about the practical requirements seems to be better.

The table above shows that at least 61 (48.8\%) declared that $\mathrm{CW}$ is not a daily statutory requirement. However, $38(30.4 \%)$ indicated that it is, $23(18.4 \%)$ didn't know and $3(2.4 \%)$ did not respond.

These results reveal that the majority 84 (67.2\%) among this cohort were unaware and do not appear to know the legal position of $\mathrm{CW}$ in schools. It is possible that the results reflect their expectation that CW would not be something that is legislated. Thus, this has implication for their training in terms of informing trainees of this legal requirement so that after qualifying, they contribute and support schools to meet their obligation, should they wish to do so.

The table shows that 117 (93.6\%) indicated that parents have a legal right to withdraw their children from CW. It is encouraging to observe that knowledge about this legal provision is well known and promoted among these respondents. However, it is interesting to observe that although $93.6 \%$ knew that parents have a legal right of withdrawal at least $67.2 \%$ seemed unaware of $\mathrm{CW}$ being statutory. 
In responding to the statement that CW must take place in the morning, 105 (84\%) respondents declared that it did not have to take place in the morning. However 14 (11.2\%) didn't know. This seems to be a reflection of their awareness of the fact that CW is and can be held at any time during the school day. It is likely that this has been informed by observations or experiences in schools. Perhaps, they recognise that schools are busy places and stipulating a specific time might be impractical.

In response to the statement that teachers have no choice - it is compulsory for them to deliver CW, 20 respondents (16\%) selected the true option. However, 73 (58.4\%) indicated that they do have a choice and $28(22.4 \%)$ did not know.

This shows that at least $16 \%$ of these respondents think that it is a compulsory requirement for teachers to deliver $\mathrm{CW}$, whereas just under a quarter did not know. The affirmative responses may be based on their assumption that everything that happens in school is 'compulsory' for teachers to do, hence CW would be similar. It is also possible that this is a reflection of worship and/or prayer in a faith school, where some of these respondents might have learnt that it is compulsory for some teachers to deliver CW in those schools.

[Table 2 near here]

\begin{tabular}{|c|c|c|c|c|c|c|c|c|c|c|c|c|}
\hline \multirow[b]{2}{*}{$\begin{array}{l}\text { I think CW makes a } \\
\text { significant contribution } \\
\text { to moral development }\end{array}$} & \multicolumn{2}{|c|}{$\begin{array}{l}\text { Strongly } \\
\text { Agree }\end{array}$} & \multicolumn{2}{|c|}{ Agree } & \multicolumn{2}{|c|}{ Neutral } & \multicolumn{2}{|c|}{ Disagree } & \multicolumn{2}{|c|}{$\begin{array}{l}\text { Strongly } \\
\text { Disagree }\end{array}$} & \multicolumn{2}{|c|}{$\begin{array}{l}\text { Missing } \\
\text { Data }\end{array}$} \\
\hline & 14 & $11.2 \%$ & 74 & $59.2 \%$ & 31 & $24.8 \%$ & 2 & $1.6 \%$ & 0 & 0 & 4 & $3.2 \%$ \\
\hline $\begin{array}{l}\text { I think CW makes a } \\
\text { significant contribution to } \\
\text { spiritual development }\end{array}$ & 18 & $14.4 \%$ & 63 & $50.4 \%$ & 39 & $31.2 \%$ & 2 & $1.6 \%$ & 0 & 0 & 3 & $2.4 \%$ \\
\hline $\begin{array}{l}\text { I think CW should be } \\
\text { abolished from school }\end{array}$ & 2 & $1.6 \%$ & 3 & $2.4 \%$ & 15 & $12 \%$ & 56 & $44.8 \%$ & 45 & $36 \%$ & 4 & $3.2 \%$ \\
\hline $\begin{array}{l}\text { I think CW makes a } \\
\text { significant contribution to } \\
\text { social development }\end{array}$ & 12 & $9.6 \%$ & 60 & $48 \%$ & 44 & $35.2 \%$ & 3 & $2.4 \%$ & 0 & 0 & 6 & $4.8 \%$ \\
\hline $\begin{array}{l}\text { I think CW makes a } \\
\text { significant contribution to } \\
\text { cultural development }\end{array}$ & 27 & $21.6 \%$ & 67 & $53.6 \%$ & 22 & $17.6 \%$ & 2 & $1.6 \%$ & 2 & $1.6 \%$ & 5 & $4 \%$ \\
\hline $\begin{array}{l}\text { I think CW confuses } \\
\text { children's faith position }\end{array}$ & 3 & $2.4 \%$ & 20 & $16 \%$ & 50 & $40 \%$ & 41 & $32.8 \%$ & 7 & $5.6 \%$ & 4 & $3.2 \%$ \\
\hline $\begin{array}{l}\text { I think CW makes a } \\
\text { significant contribution to } \\
\text { emotional development }\end{array}$ & 10 & $8 \%$ & 56 & $44.8 \%$ & 50 & $40 \%$ & 6 & $4.8 \%$ & 0 & 0 & 3 & $2.4 \%$ \\
\hline
\end{tabular}




\begin{tabular}{|l|l|l|l|l|l|l|l|l|l|l|l|l|}
\hline \multicolumn{2}{|l|}{$\begin{array}{l}\text { Strongly } \\
\text { Agree }\end{array}$} & \multicolumn{2}{l|}{ Agree } & \multicolumn{2}{l|}{ Neutral } & \multicolumn{2}{l|}{ Disagree } & \multicolumn{2}{l|}{$\begin{array}{l}\text { Strongly } \\
\text { Disagree }\end{array}$} & \multicolumn{2}{l}{$\begin{array}{l}\text { Missing } \\
\text { Data }\end{array}$} \\
\hline $\begin{array}{l}\text { I think CW makes a } \\
\text { significant contribution to } \\
\text { intellectual development }\end{array}$ & 7 & $5.6 \%$ & 35 & $28 \%$ & 65 & $52 \%$ & 13 & $10.4 \%$ & 2 & $1.6 \%$ & 3 & $2.4 \%$ \\
\hline $\begin{array}{l}\text { I think CW makes a } \\
\text { significant contribution to } \\
\text { the ECM agenda }\end{array}$ & 12 & $9.6 \%$ & 46 & $36.8 \%$ & 55 & $44 \%$ & 5 & $4 \%$ & 1 & $0.8 \%$ & 6 & $4.8 \%$ \\
\hline
\end{tabular}

The fifth section of the questionnaire asked participants to indicate, on a five point Likert scale, the intensity of their agreement or disagreement on nine statements regarding the contribution that they thought CW makes to pupils' development.

\section{Moral development}

88 (70.4\%) agree that CW makes a significant contribution to the moral development of pupils, of which 14 (11.2\%) went further and strongly agreed. However, 31 (24.8\%) were noncommittal when responding to this statement.

A quarter of these participants took a neutral stance which is surprising as it is expected that CW promotes common ethos, shared values and moral development in school (DFE 1994; REC 1998). However, the majority seem to concur with the idea that CW serves a socio-moral purpose as reported by Gill (2004). Thus, some schools are orientated towards ethical ideas. Smith and Smith (2013) found that almost all assemblies in their study sample communicated a form of virtue ethics which led them to conclude that virtues seem to transcend the problems of pluralism and secularism in a way which values cannot. This, according to them, made virtues a good working solution for schools.

\section{Spiritual development}

$81(64.8 \%)$ agree that CW makes a significant contribution to spiritual development, of which 18 (14.4\%) went further and strongly agreed. However, 39 (31.2\%) were non-committal when responding to this statement.

Fewer disagree, perhaps, due to the close relationship between $\mathrm{CW}$ and spiritual development. Just over a third were non-committed to the role of $\mathrm{CW}$ making a significant contribution to spiritual development of pupils, even though CW appeals to many teachers (Cheetham 2004) and is seen as one of the principle areas of school life for fostering spiritual development (Gay 2000). Moreover, Davies (1998) reported that whilst there was a variety of interpretations, as far as contributions to spiritual development made by different aspects of school life was concerned, nearly all his respondents felt school worship and ethos played an important part in this.

\section{Abolished}


The controversial nature of $\mathrm{CW}$ in state schools prompted the need to question its continued existence. These trainees were asked whether they thought $\mathrm{CW}$ should be abolished from schools. In response, 101 (80.8\%) disagree that CW should be abolished, of which 45 (36\%) went further and strongly disagreed. However, 15 (12\%) were non-committal when responding to this statement. 5 (4\%) agree that CW should be abolished from school, of which $2(1.6 \%)$ went further and strongly agreed.

There appears to be a strong correlation between the contribution that $\mathrm{CW}$ makes to the development of children and maintaining it in school. It is fascinating to note that responses to this statement are the highest among all the responses in the disagree options and, overall, this statement seems to have attracted the fourth strongest responses among all the statements.

\section{Social development}

72 (57.6\%) agree that CW makes a significant contribution to social development, of which 12 (9.6\%) went further and strongly agreed. However, 44 (35.2\%) were non-committal when responding to this statement.

A higher response was expected for this statement since social development is one part of spiritual, moral, social and cultural development. However, as with the responses to spiritual development, the $35 \%$ non-committal response is surprising since $\mathrm{CW}$ is supposed to be, in practice, a communal occasion where pupils are expected to come together. During this time students desire to explore matters related to social life (Gill 2004). In other words, CW creates many opportunities for teachers who seek common grounds to achieve these as part of CW.

\section{Cultural development}

94 (75.2\%) agree that CW makes a significant contribution to cultural development, of which 27 (21.6\%) went further and strongly agreed. However, 22 (17.6\%) were non-committal when responding to this statement. In this instance, 4 (3.2\%) disagree that CW makes a significant contribution to cultural development, of which $2(1.6 \%)$ went further and strongly disagreed.

This has received the highest responses. Over three quarters of the respondents agree that $\mathrm{CW}$ makes a significant contribution to cultural development. Perhaps this is a reflection of the expectation that in a multi-faith society, CW would consist of religious and cultural traditions being imparted even though worship has to be Christian orientated. Nevertheless, students view CW as an opportunity for learning about current events, social and moral issues; values and behaviour; school events; the lives of contemporary and historic figures and other faiths and cultures (Gay 2000).

\section{Confusion}

In response to the statement about whether CW confuses children's faith position, $50(40 \%)$ were non-committal when responding. Of those who responded, 48 (38.4\%) disagreed that CW confuses children's faith position, of which 7 (5.6\%) went further and strongly disagreed. On the other hand, 23 (18.4\%) agreed that CW confuses children's faith position, of which 3 (2.4\%) strongly agreed. 
There are many challenges confronting teachers in relation to $\mathrm{CW}$. Of the nine major ones identified by Cheetham (2004), he includes the influence of the teacher's own beliefs on pupils. For some people, CW creates major challenges and tensions in the school context as $\mathrm{CW}$ is offered to 'vulnerable' children and has the potential of compromising their faith position. Nearly $20 \%$ of these trainees thought that CW confuses children's faith position whereas almost a double of this disagreed. The conscience clause, as argued by Louden (2004) has been provided to enable parents to express a conscientious objection to the type of worship provided in schools.

\section{Emotional development}

66 (52.8\%) agree that CW makes a significant contribution to emotional development, of which $10(8 \%)$ went further and strongly agreed. However, 50 (40\%) were non-committal when responding to this statement.

The spiritual, moral, social and cultural development of children features commonly in the literature linked to CW (REC 1998; Gay 2000; Gill 2004; Cheetham 2004; Ofsted 2007; Smith and Smith 2013). However, there appears to be little exploring the emotional development of pupils through and/or during CW. As with other aspects there would be concern and uncertainty about this and the ways in which it can be promoted. This is understandable in view of the conceptual difficulties with the term, nevertheless, it is argued that more needs to be discovered about the role of $\mathrm{CW}$, if any, in the emotional and intellectual development of pupils.

\section{Intellectual development}

In response to the statement about whether $\mathrm{CW}$ makes a significant contribution to intellectual development, 65 (52\%) were non-committal when responding. Of those who responded, 42 (33.6\%) agreed that CW makes a significant contribution, of which 7 (5.6\%) went further and strongly agreed. On the other hand, 15 (12\%) disagreed that CW makes a significant contribution to intellectual development, of which 2 (1.6\%) strongly disagreed.

The dominant discourse, as noted above, in terms of the benefits of $\mathrm{CW}$ remain mainly within the domain of SMSC. The statement on emotional and intellectual development through $\mathrm{CW}$ were included to uncover from these trainees other possible areas which CW could promote. There appears to be a sense that CW focusses on SMSC and less so on emotional and intellectual development. Intellectual development attracted the least agreements and highest non-committal responses.

\section{Conclusions}

This study set out to investigate trainee teachers' knowledge, understanding, viewpoints and perceptions about CW and matters related to it in primary schools. This article presented their awareness and familiarity regarding the legal status of $\mathrm{CW}$ and its value in terms of the extent to which $\mathrm{CW}$ contributes to the spiritual, moral, social, cultural, emotional and intellectual development of children.

It should be noted that the research sample, drawn from a single institute, was a convenience sample of predominantly female, young, Christian and white British individuals training to be teachers. As a survey question, the contentious requirements such as withdrawing and for 
acts of worship to be wholly, or mainly of a broadly Christian character need to be included in future research. In addition, the use of this survey questionnaire with more diverse samples will be helpful in understanding its application. That being said, data provided by 125 participants informed the following conclusions.

First, the knowledge base regarding the legal complexities of CW appear to be in need of addressing. In this regard, two key areas have emerged from this survey which require strengthening: the knowledge that it is a statutory requirement for schools to offer $\mathrm{CW}$ on a daily basis, that teachers have a choice in whether or not they deliver $\mathrm{CW}$ and that parents have a right to withdraw their children from $\mathrm{CW}$.

Second, the picture that is emerging, amongst teachers in training, is that of a will for $\mathrm{CW}$ to continue to exist. A large majority think that $\mathrm{CW}$ should remain a feature of schools. Here are future teachers whose views suggest that $\mathrm{CW}$ is perceived to be part of the provisions being made by contemporary schools to children living in a multi-faith and multicultural society. In addition, it seems that in the philosophy of education of some people, a place is found for CW to exist within secular settings. This being the case, any future action in relation to $\mathrm{CW}$ would be well assisted by considering it from plural perspectives to attend to the diverse positions reflected in society.

Third, the multifaceted nature of the contributions that an activity such as CW, even with its ambiguous nature, has been confirmed amongst teachers in training. Other than intellectual development, every other aspect of SMSC and emotional development is over $66 \%$. In other words, the data gives the impression that these participants attached considerable value in having $\mathrm{CW}$ in schools.

Fourth, the most significant contribution, it seems, is made to their cultural development, followed by moral, spiritual, social, emotional and intellectual development, respectively. It also makes a significant contribution to the ECM agenda, which were the five outcomes which mattered most to children: to be healthy; to stay safe; to enjoy and achieve; to make a positive contribution and to achieve economic well-being.

Following from the above, fifth, the aims and content being delivered in schools appears to be wide ranging and suggests that some schools use $\mathrm{CW}$ to contribute to more than the aims set out in Circular 1/94 (DfE 1994). Perhaps this is a reflection of the role of CW being conceived as one which should be relevant to the times and lives of the pupils and communities it is meant to serve.

\section{References}

Arthur, J. 2015. "Extremism and Neo-Liberal Education Policy: A Contextual Critique of the Trojan Horse Affair in Birmingham Schools." British Journal of Educational Studies, 63 (3): 311-328.

BCC (Birmingham City Council). 2014. Trojan Horse Review Group, Report to Leader of Birmingham City Council. Birmingham: Birmingham City Council. Accessed January 32016. http://www.birmingham.gov.uk/trojanhorsereview 
BHA (British Humanist Society). 2015. Collective Worship. Accessed December 232015. https://humanism.org.uk/campaigns/schools-and-education/collective-worship/

Bingham, J. 2014. "Compulsory Christian school assembly should be scrapped - Church of England education chief". Telegraph, December 262015. http://www.telegraph.co.uk/education/educationnews/10951894/Compulsory-Christianschool-assembly-should-be-scrapped-Church-of-England-education-chief.html

Brighouse, T. 2014. "The curious incident of the Trojan Horse in the middle of Birmingham: Twenty questions to solve the mystery". Times Education Supplement. December 262015. https://www.tes.com/news/school-news/breaking-views/curious-incident-trojan-horsemiddle-birmingham-twenty-questions\#.U5iJQFj6PjK.twitter

Butler-Sloss, E. 2015. Living with Difference community, diversity and the common good. Cambridge: Woolf Institute. Accessed December 242015. https://corablivingwithdifference.files.wordpress.com/2015/12/living-with-differenceonline.pdf

Cheetham, R. 2000. "'Collective Worship: A Window into Contemporary Understandings of the Nature of Religious Belief?'." British Journal of Religious Education, 22 (2): 71-81.

Cheetham, R. 2004. Collective Worship: Issues and Opportunities. London: Society for Promoting Christian Knowledge.

Clarke, P. 2014. Report into allegations concerning Birmingham schools arising from the 'Trojan Horse' letter. London: Department for Education.

Clarke, C., and L. Woodhead. 2015. A New Settlement: Religion and belief in schools. Lancaster: Westminster Faith Debates. Accessed December 242015. http://faithdebates.org.uk/wp-content/uploads/2015/06/A-New-Settlement-for-Religionand-Belief-in-schools.pdf

Colverd, S, and B. Hodgkin. 2011. Developing Emotional Intelligence in the Primary School. London: Routledge

Creswell, J. 2014. Research design: qualitative, quantitative, and mixed methods approaches. 4th ed. London: SAGE.

Cumper, P., and A. Mawhinney, eds. 2015. Collective Worship and Religious Observance in Schools: An evaluation of law and policy in the UK. Swindon: Arts and Humanities Research $\begin{array}{llll}\text { Council. } & \text { Accessed } & \text { December } & 23\end{array}$ http://collectiveschoolworship.com/documents/CollectiveWorshipReligiousObservanceAHR CNetworkReport13November2015 000.pdf

Curtis, Will, Mark Murphy, and Sam Shields. 2014. Research and Education. Abington: Routledge. 
Davies, G. 1998. "What is Spiritual Development? Primary Headteachers' Views." International Journal of Children's Spirituality 3 (2): 123-133.

DfE (Department for Education). 1994. Religious Education and Collective Worship. London: Department for Education.

Felderhof, M. C. 2000. "'On Understanding Worship in School Part Two: on worship and educating'." Journal of Beliefs \& Values 21 (1): 17-26.

Gay, B. 2000. "'Fostering Spiritual Development through the Religious Dimension of Schools: the report of a pilot study in 17 independent schools'." International Journal of Children's Spirituality 5 (1): 61-74.

Gill, J. 2004. "The act of collective worship: pupils' perspectives'." British Journal of Religious Education 26 (2): 185-196.

HMSO (Her Majesty's Stationery Office). 2015. Extremism in Schools: the Trojan Horse affair, 17 March 2015. House of Commons. HC 473 2014-15. London: Stationery Office.

HMSO (Her Majesty's Stationery Office). 2003. Every Child Matters. Norwich: HMSO.

Huppert, J. 2010. Collective Worship, early day motion 395. Accessed December 232015. http://www.parliament.uk/edm/2010-12/395

Kershaw, I. 2014. Investigation Report: Trojan Horse letter - Report of lan Kershaw of Northern Education for Birmingham City Council in respect of issues arising as a result of concerns raised in a letter dated 27 November 2013, known as the Trojan Horse letter. London: Eversheds.

Khan, A. 1995. "Daily Collective Worship and Religious Education in British School." Journal of Law and Education 24 (4): 601-612.

Louden, Lois M. R. 2004. "'The conscience clause in religious education and collective worship: conscientious objection or curriculum choice?'." British Journal of Religious Education 26 (3): 273-284.

Mogra, I. 2016. The "Trojan Horse" affair and radicalisation: an analysis of Ofsted reports, Educational Review, DOI: 10.1080/00131911.2015.1130027

Neuman, W.L. 2014. Social research methods: qualitative and quantitative approaches. 7th ed. Harlow: Pearson.

Ofsted (Office for Standards in Education). 2007. Religious education and collective worship An analysis of 2006 SACRE reports. QCA/07/3253. London: HMSO.

Ofsted (Office for Standards in Education). 2014a. School Report Nansen Primary School - A Park View Academy. Accessed February 05 2016. http://reports.ofsted.gov.uk/inspectionreports/find-inspection-report/provider/ELS/138799 
Ofsted (Office for Standards in Education). 2014b. School Report Oldknow Academy. Accessed February 05 2016. http://reports.ofsted.gov.uk/inspection-reports/find-inspectionreport/provider/ELS/138052

Ofsted (Office for Standards in Education). 2014c. School Report Welford Primary School. Accessed February 052016 . http://reports.ofsted.gov.uk/inspection-reports/findinspection-report/provider/ELS/103328

Parker, S.G., R.J.K. Freathy, and L.J. Francis. 2014. History, Remembrance and Religious Education. Oxford: Peter Lang.

Pecenka, P., and F. Anthias. 2014. "Minority Faith Schools as Claims for Cultural Recognition? Two Examples from England." Identities: Global Studies in Culture and Power 22: 433-450.

Pope, G. 2014. Catholic school governors and Anglican bishop divided over school assemblies. Accessed December 24 2015. http://www.ionainstitute.net/index.php?id=3627

REC (Religious Education Council). 1998. Collective Worship reviewed. Report of the 1997 consultation. Abingdon: Culham College Institute.

Smith, G., and S. Smith. 2012. "From values to virtues: an investigation into the ethical content of English primary school assemblies." British Journal of Religious Education 35 (1): 5-19. 